\title{
Identification of potential acid sulfate soils at the Reda River mouth (northern Poland) using pH measurements
}

\author{
Piotr Hulisz ${ }^{1,2}$, Adam Michalski², Anton Boman³, Michał Dąbrowski², Wojciech Kwasowski ${ }^{4}$ \\ ${ }^{1}$ Department of Soil Science and Landscape Management, Faculty of Earth Sciences and Spatial Management, Nicolaus Copernicus University, \\ ul. Lwowska 1, Toruń, Poland \\ ${ }^{2}$ Laboratory for Environmental Analysis, Faculty of Earth Sciences and Spatial Management, Nicolaus Copernicus University, ul. Lwowska 1, \\ Toruń, Poland \\ ${ }^{3}$ Geological Survey of Finland, PO Box 97, Teknologiakatu 7, FI-67101 Kokkola, Finland \\ ${ }^{4}$ Department of Soil Science, Institute of Agriculture, Warsaw University of Life Sciences - SGGW, ul. Nowoursynowska 159, 02-776, Warsaw, \\ Poland \\ * Dr hab. Piotr Hulisz, prof. UMK, hulisz@umk.pl, ORCID iD: http://orcid.org/0000-0003-3494-9997
}

Received: October 9, 2019

Accepted: April 22, 2020

Associated editor: C. Kabała

\section{Keywords}

Acid sulfate soils

Baltic Sea

Incubation

Organic soils

PASS

Soil classification

\begin{abstract}
The definition of sulfidic material (in Polish: materiat siarczkowy) was first introduced in the 6th edition of the Polish Soil Classification in 2019, but the methods of identifying potential acid sulfate soils (PASS) using pH measurements had not earlier been applied in Poland. Therefore, the aim of this paper is to compare two simple tests approved as international standards and recommended in the Polish Soil Classification - incubation method and hydrogen peroxide tests - to identify PASS in three soil profiles in the Baltic coastal area (Reda River mouth, northern Poland). In the first test, soil pH (1:1 soil-to-water suspension) was determined in newly taken soil samples and after incubation for 8 weeks at room temperature. Initial pH values varied from 5.5 to 7.0, and after 8 weeks of incubation dropped below pH 4 in two of the three soil profiles. In the second test, freshly collected samples, after initial $\mathrm{pH}$ measurement, were oxidised in $30 \%$ hydrogen peroxide. Application of this strong oxidising agent drastically decreased $\mathrm{pH}$ values to below $2.5 \mathrm{in}$ all three soil profiles. The $\mathrm{pH}$ measurements both after incubation and after application of hydrogen peroxide allow for an unequivocal identification of the sulfidic material, thus confirming the presence of PASS in the Reda River mouth area. Both tests based on pH measurements are easy to perform and low-cost, which implies their common application in PASS recognition. However, careful attention should be paid to some limitations of the hydrogen peroxide test - mainly, the possible overestimation of acidity in organic samples. This procedure should therefore be considered only as complementary. Because of the dominance of organic PASS materials in Polish soils, a modification of the $\mathrm{pH}$ criterion for the sulfidic material was proposed in accordance with the approach used in the Finnish-Swedish classification.
\end{abstract}

\section{Introduction}

Potential acid sulfate soils (PASS) are coastal, inland or mine spoil soils with a high content of iron sulfides. Originally neutral or alkaline, and often with a low buffer capacity, these soils have the potential to produce sulfuric acid if drained or excavated (actual acid sulfate soils) (Pons, 1973; Dent and Pons, 1995). The problem associated with sulfide oxidation is the release of toxic substances (mainly heavy metals), which can be leached and transported in very acidic ( $\mathrm{pH}<4$ ) environments (Fältmarsch et al., 2008). Acid sulfate soils are commonly considered a serious global hazard, with a remarkably negative impact on ecosystems and human health (Dent and Pons, 1995; Andriesse and Van Mensvoort, 2006).
Acid sulfate soil material is classified according to the presence of diagnostic properties such as hypersulfidic and sulfuric materials (Sullivan et al., 2010). Hypersulfidic material is described as sulfidic material ( $\geq 0.01 \%$ inorganic sulfidic $S$ ), which upon incubation (i.e. oxidation) at field capacity (generally at least 8 weeks) displays a $\mathrm{pH}$ drop of $\geq 0.5$, compared to unoxidised conditions, to a value of $<4$. During field conditions, oxidation of hypersulfidic materials often leads to the development of a sulfuric horizon $(\mathrm{pH}<4)$. Both diagnostic materials are recognised in the World Reference Base for Soil Resources classification (IUSS Working Group WRB, 2015), with “sulfuric” being referred to as "thionic". Sulfidic material that does not display a drop in $\mathrm{pH}$ to $<4.0$ is termed "hyposulfidic". In Finland and Sweden, a lower diagnostic limit of $\mathrm{pH}<3.0$ for recognition of hypersulfidic 
and sulfuric material in organic soil material (e.g. peat, gyttja) is currently used in order to distinguish between acidity formed due to sulfide oxidation and that originating from organic acids (Boman et al., 2018).

Additionally, a screening test by rapid sample oxidation with $30 \% \mathrm{H}_{2} \mathrm{O}_{2}$ (1:5 soil-to-peroxide suspension) can be used. PASS materials are then recognised if the $\mathrm{pH}$ value decreases to 2.5 or below (IUSS Working Group WRB, 2015).

As evidenced by Hulisz et al. (2017), organic (peat and mud) and mineral-organic, carbonate-poor PASS predominate in Poland. There are dozens of PASS sites (ranging in size from a few to several dozen hectares) located along the Baltic Sea coast (Pracz, 1989; Kwasowski, 1999; Niedźwiecki et al., 2000, 2002; Hulisz, 2013), inland areas affected by saline spring waters (Czerwiński, 1996; Hulisz, 2007), and mining areas (Uzarowicz and Skiba, 2011; Uzarowicz, 2013). Unfortunately, the total area occupied by these soils has not been estimated yet. Much of the previous research has been focused on the basic physical and chemical properties of acid sulfate soils in Poland. Therefore, it is necessary to conduct more detailed research on PASS, involving soil mapping, estimation of environmental risk, as well as implementation of a unified methodological identification approach, especially because these soils may occur in both naturally valuable and agricultural areas.

Unfortunately, a definition of PASS was not included in the previous Polish Soil Classifications. Criteria for sulfidic material (in Polish: materiat siarczkowy) were introduced for the first time in the recent, sixth edition of the Polish Soil Classification (Systematyka gleb Polski, 2019). The diagnostic criteria for materiał siarczkowy generally refer to international standards and correspond to hypersulfidic material (IUSS Working Group WRB, 2015; Boman et al., 2018), but seasonal or permanent waterlogging is required. Moreover, the inorganic sulfidic sulfur content has been replaced with a ratio of organic carbon to total sulfur at $\leq 20$. Indication of sulfidisation may be added as a variety - a new non-hierarchical classification category (Kabała et al., 2019). In contrary to the Finnish-Swedish classification (Boman et al., 2018), there are no separate pH limits for organic and mineral soil materials.

Except for the study by Urbańska et al. (2012), the methods of PASS identification using $\mathrm{pH}$ measurements have not previously been extensively applied in Poland. Therefore, the purpose of this paper is to determine the usefulness of two tests (i.e. the incubation and hydrogen peroxide tests) to identify PASS in Poland. The results will allow verification of the PASS classification criteria in the sixth edition of the Polish Soil Classification (Systematyka gleb Polski, 2019). The Reda River mouth was selected as the test site following previous research by Pracz and Kwasowski (2006). This is probably one of the largest areas of acid sulfate soils in Poland. In this work, the experience on acid sulfate soils in Finland, where the problem of soil acidification due to these soils is a major environmental threat, was also utilised.

\section{Study area}

The study area (Fig. 1) comprises the flat alluvial coast of the Puck Lagoon connected with the Reda and Płutnica ice-marginal valleys within the geographical region of Pobrzeże Kaszubskie in northern Poland (Kondracki, 2001). The bottoms of these valleys are mostly filled with Holocene peats with a thickness ranging from about 2 to $7 \mathrm{~m}$ (Pracz and Kwasowski, 2005; Jegliński, 2009). According to Uścinowicz (2006), the calibrated ${ }^{14} \mathrm{C}$ age of these peat deposits can be estimated at 2222-1268 BC (depth of 1.02-1.06 m b.s.l.) and 647-997 AD (depth of 0.40-0.45 m b.s.l.).

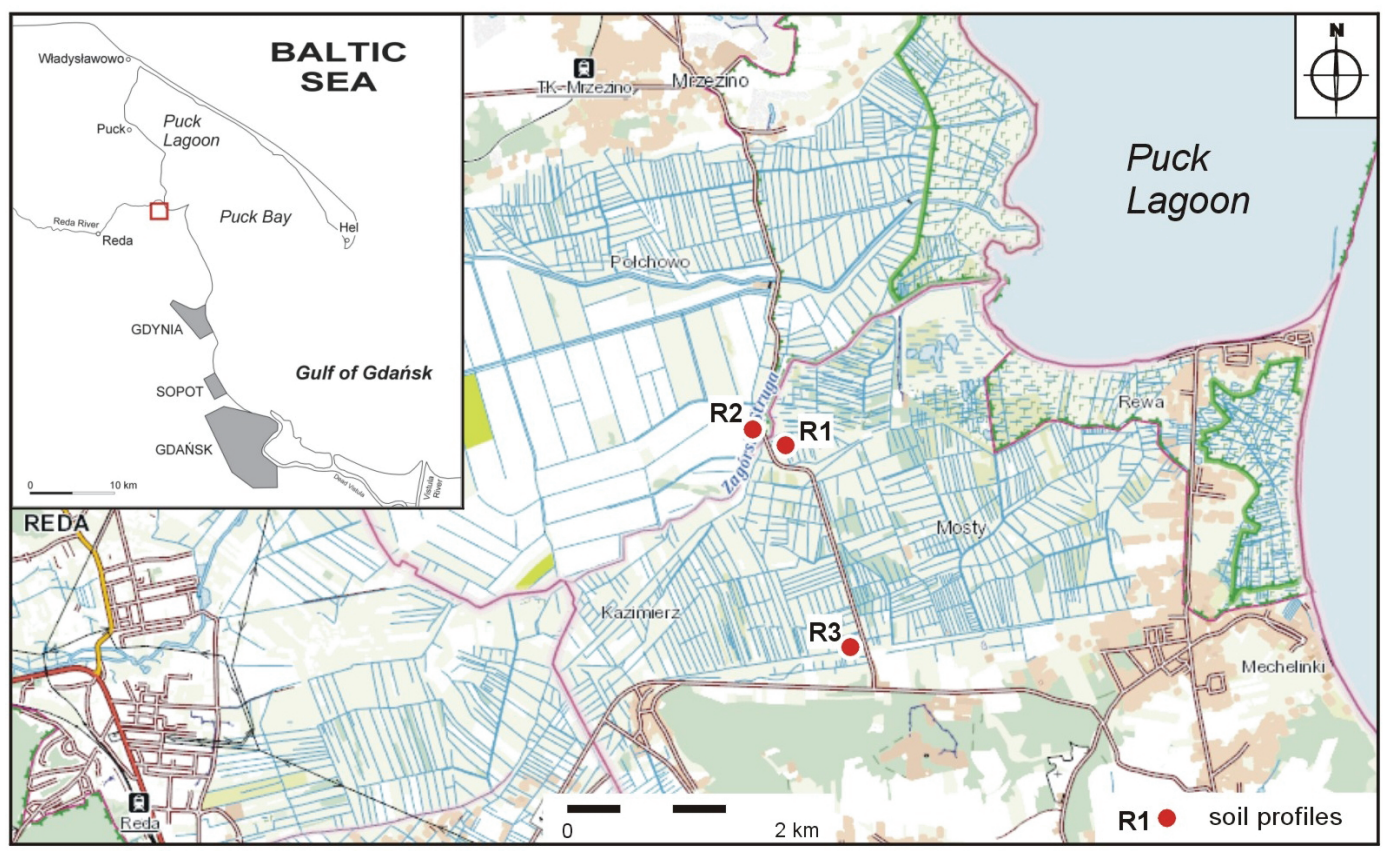

Fig. 1. Location of the study area and soil profiles 
The total area of the peatland is about 2,950 ha (Staszek and Kistowski, 1999). The soil cover is dominated by saline soils and acid sulfate soils, mostly drained and used as meadows and pastures (Pracz and Kwasowski, 2006). PASS in the study area occur in complexes with actual acid sulfate soils. The soils were developed from wetland deposits during contact with sulfaterich seawater and organic sulfide deposits developed due to the continuous and long-term supply of sulfate-rich brackish water.

PASS are environmentally stable and their properties do not undergo larger modifications in wetland environments, i.e. under the influence of anoxic conditions. These soils undergo intense modifications during dewatering of an area. The oxidation of sulfides and the formation of free sulfuric acid result in their transition into extremely acid soils and soil classification as actual acid sulfate soils. Such strong acidification results in a number of changes unfavourable to the environment. Due to the acidic conditions, metals may be mobilised in enormous quantities from these soils into the aquatic environments, which has a negative impact on living organisms. Even more hazardous to the environment is the diffusion of these ions to groundwater. Strong pollution by metals and strongly acidified water may cause the death of many fish species and other water organisms, significantly decreasing the biodiversity of water and wetland ecosystems (Dent and Post, 1995; Smith and Melville, 2004). Strong water acidification also causes economic losses related to increased corrosion of metal elements, i.e. pipes, culverts and bridges, or even the destruction of concrete objects.

\section{Materials and methods}

The study was carried out in 2018. Three sampling sites were selected on the basis of previous research by Pracz and Kwasowski (2006) as shown in Fig. 1. An Instorf drill was used to collect three soil profiles (24 samples in total taken from genetic horizons). The following determinations were made in each bulk soil sample: potential redox (Eh) against a reference electrode $(\mathrm{Ag} / \mathrm{AgCl})$ by the potentiometric method, and apparent electrical conductivity $\left(\mathrm{EC}_{\mathrm{a}}\right.$ ) using Time Domain Reflectometry (TDR).

All fresh/moist soil samples were submitted for incubation following procedures presented elsewhere (e.g. Creeper et al., 2012; Mattbäck, et al. 2017). In 1-cm-thick layers, samples were incubated in $50 \mathrm{ml}$ Falcon plastic tubes under moist aerobic conditions (field capacity) at room temperature for 8 weeks. Incubation $\mathrm{pH}$ was measured potentiometrically using an Elmetron flat EPX-3 electrode at the start of the incubation (referring to the actual field conditions) and after 1, 2, 3, 4, 6 and 8 weeks. These measurements were designated $\mathrm{pH}_{0 \mathrm{w}}, \mathrm{pH}_{1 \mathrm{w}}, \mathrm{pH}_{2 \mathrm{w}}, \mathrm{pH}_{3 \mathrm{w}}$, $\mathrm{pH}_{4 \mathrm{w}}, \mathrm{pH}_{6 \mathrm{w}}, \mathrm{pH}_{8 \mathrm{w}}$, respectively. Before each of the incubation $\mathrm{pH}$ measurements, deionised water was added to each sample at a ratio of ca. 1:1 and then stirred with a glass rod. Stirring enables better contact between the soil material and the electrode, and helps to avoid any potential heterogeneities formed during oxidation (Mattbäck et al., 2017).
The laboratory analysis of air-dried soils included determination of the organic matter content as loss on ignition (Loi) in a muffle furnace at a temperature of $550^{\circ} \mathrm{C}(3 \mathrm{~h})$ and the calcium carbonate content by the Scheibler's method. Additionally, the $\mathrm{pH}$ of 1:5 fresh soil/hydrogen peroxide suspension was determined for identification of PASS material following the guidelines in WRB (IUSS Working Group WRB, 2015). The pH of 30\% $\mathrm{H}_{2} \mathrm{O}_{2}$ was adjusted to $\mathrm{pH} 4.5-5.5$ using $0.01 \mathrm{M} \mathrm{NaOH}$ before the measurement (Jayalath, 2012).

In order to enable identification of reducing conditions, the negative logarithm of hydrogen partial pressure $(\mathrm{rH})$ was calculated from $\mathrm{pH}_{0 \mathrm{w}}$ and Eh values (FAO, 2006; IUSS Working Group WRB, 2015).

\section{Results}

\subsection{Basic properties of the studied PASS}

The studied soils were developed from organic material such as muck, peat and gyttja (21 samples). Mineral deposits such as sands ( 3 samples) occurred at various depths, between $50 \mathrm{~cm}$ (profile R2) and more than $310 \mathrm{~cm}$ (profile R3) - Fig. 2. Selected properties of PASS are presented in Table 1 . The $\mathrm{rH}$ values between 19 and 28 indicated prevailing transitional redox conditions. The lowest Eh values (below $200 \mathrm{mV}$ ) were recorded at the bottom of profiles $\mathrm{R} 2$ and $\mathrm{R} 3$. The organic matter content was very diverse (LOI $0.5-91 \%$; mean $70.0 \% \pm 29.3 \%$ ) and the content of $\mathrm{CaCO}_{3}$ did not exceed $2.1 \%$ (mean $0.8 \% \pm 0.6 \%$ ) - Fig. 2. The $\mathrm{EC}_{\mathrm{a}}$ values ranged from 0.1 to $2.0 \mathrm{dS} \cdot \mathrm{m}^{1}$, implying brackish conditions, which is typical for Polish coastal marsh soils (Hulisz et al., 2016).

\subsection{Changes in $\mathrm{pH}$ during sample incubation and peroxide} tests

The initial incubation $\mathrm{pH}$ values $\left(\mathrm{pH}_{0 \mathrm{w}}\right)$ for organic and mineral soil materials varied from 5.5 to 6.6 and from 6.1 to 7.0, respectively (Table 1, Fig. 2). The lowest values were recorded in the organic topsoils (Fig. 2). After an eight-week incubation period $\left(\mathrm{pH}_{8 \mathrm{w}}\right)$, the $\mathrm{pH}$ values had dropped below the diagnostic $\mathrm{pH}$-criteria for sulfidic material $\left(\mathrm{pH}_{8 \mathrm{w}}<4\right.$; Systematyka gleb Polski, 2019) in eight samples (seven organic and one mineral) at the depths below $25 \mathrm{~cm}$ (highly decomposed peat and sand) and $243 \mathrm{~cm}$ (gyttja) for profiles R1 and R3, respectively. These results indicated the presence of PASS material (Fig. 2). In the R2 profile, $\mathrm{pH}_{\mathrm{pox}}$ was low $(\mathrm{pH}<3)$ but the $\mathrm{pH}_{8 \mathrm{w}}$ values were too high (pH 4.4-4.7) to identify the sulfidic material - Fig. 2.

The rate of $\mathrm{pH}$ decline was expressed as a function of time $(\Delta \mathrm{pH} / \Delta \mathrm{t})$. As shown in Figure 3, the selected samples had moderate to low acid neutralising capacities. The acidification during sample incubation was more rapid in the first two weeks for all tested soil materials. The highest differences between $\mathrm{pH}_{0 \mathrm{w}}$ and $\mathrm{pH}_{8 \mathrm{w}}(\Delta \mathrm{pH} 13.6-4.8)$ were recorded in the sulfidic materials from profiles R1 and R3 (Fig. 2), while the $\Delta \mathrm{pH} / \Delta \mathrm{t}$ values were highest (for both peat and sand samples) in profile R1 (Fig. 3). 

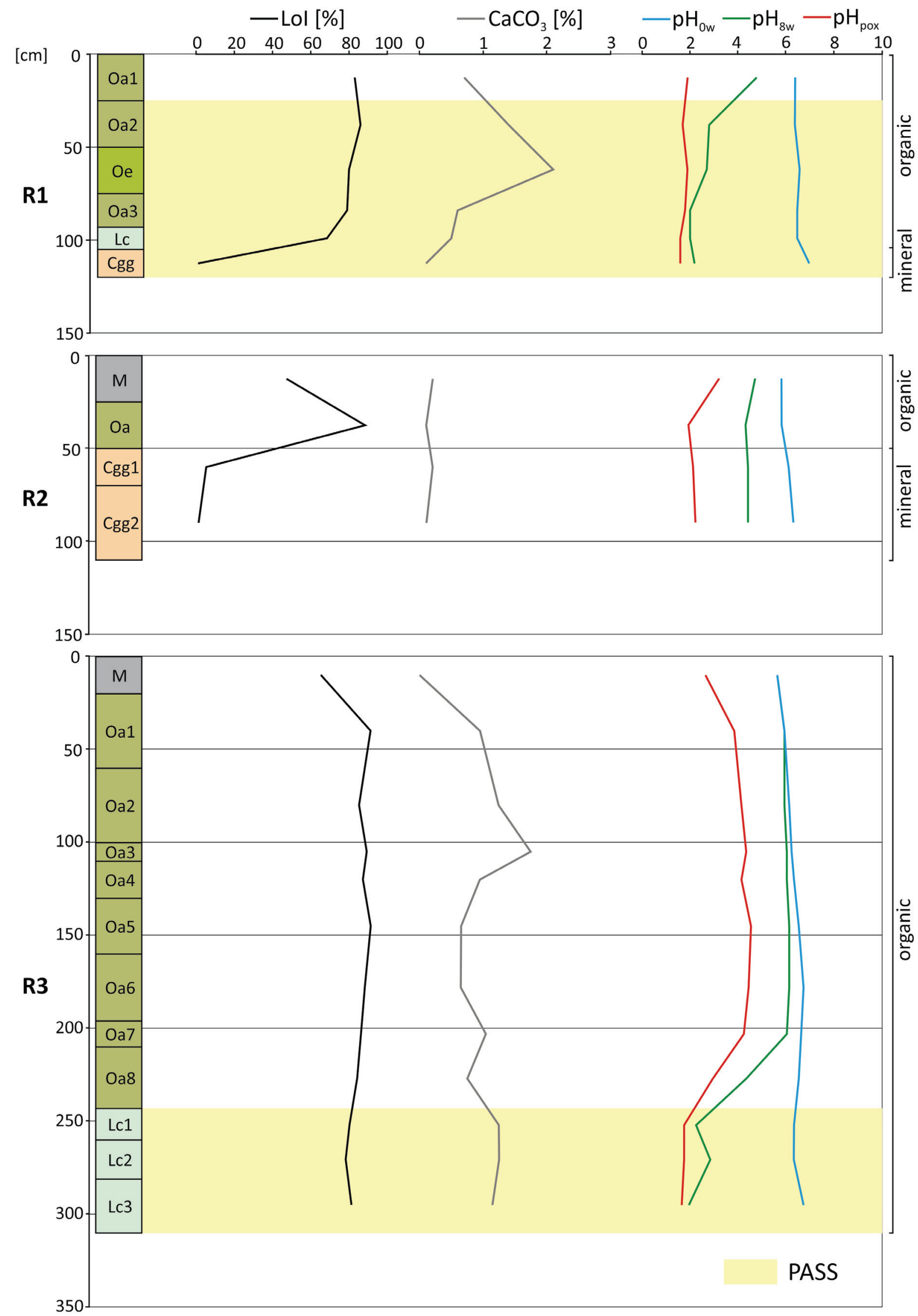

Fig. 2. Variability of selected soils properties in the studied soil profiles. Explanations of symbols: LoI - loss on ignition, $\mathrm{pH}_{0 \mathrm{w}}-\mathrm{pH}_{\mathrm{p}}$ measurement at the start of the incubation, $\mathrm{pH}_{8 \mathrm{w}}-\mathrm{pH}$ measurement at the end of the incubation (8 week), $\mathrm{pH}_{\mathrm{pox}}-\mathrm{pH}$ measurement after oxidation with $30 \% \mathrm{H}_{2} \mathrm{O}_{2}, \mathrm{PASS}$ - potential acid sulfate soil material. Symbols of soil horizons according to Polish Soil Classification (Systematyka gleb Polski, 2019) 
Table 1

Descriptive statistics of soil characteristics in the study area $(n=24)$

Explanation of symbols: $\mathrm{E}_{\mathrm{h}}$ - redox potential, $\mathrm{rH}$ - negative logarithm of the hydrogen partial pressure, LoI - loss on ignition, $\mathrm{EC}_{\mathrm{a}}$ - electrical conductivity of bulk soil, $\mathrm{pH}_{0 \mathrm{w}}$ - initial incubation $\mathrm{pH}, \mathrm{pH}_{8 \mathrm{w}}$ - incubation $\mathrm{pH}$ after 8 weeks, $\mathrm{pH}_{\mathrm{pox}}-\mathrm{pH}$ after oxidation with $30 \% \mathrm{H}_{2} \mathrm{O}_{2}, \Delta \mathrm{pH} 1=\mathrm{pH}_{0 \mathrm{w}}-\mathrm{pH}_{8 \mathrm{w}}, \Delta \mathrm{pH} 2=$ $=\mathrm{pH}_{0 \mathrm{w}}-\mathrm{pH}_{\mathrm{pox}}$

Fig. 3. Rate of pH decline caused by soil sample incubation as a function of time. Symbols of soil horizons according to Polish Soil Classification (Systematyka gleb Polski, 2019)

\begin{tabular}{llllll}
\hline Parameter & Mean & SD & Min & Max & CV [\%] \\
\hline $\mathrm{E}_{\mathrm{h}}[\mathrm{mV}]$ & 283 & 82 & 179 & 474 & 29.0 \\
\hline $\mathrm{rH}$ & 22 & 2 & 19 & 28 & 9.1 \\
\hline $\mathrm{LoI}[\%]$ & 70 & 29.3 & 0.5 & 91 & 41.9 \\
\hline $\mathrm{CaCO}_{3}[\%]$ & 0.8 & 0.6 & 0.0 & 2.1 & 75.0 \\
\hline $\mathrm{EC}_{\mathrm{a}}\left[\mathrm{dS} \mathrm{m} \mathrm{m}^{-1}\right]$ & 0.4 & 0.5 & 0.1 & 2.0 & 135 \\
\hline $\mathrm{pH}_{0 \mathrm{w}}$ & 6.3 & 0.3 & 5.5 & 7.0 & 4.8 \\
\hline $\mathrm{pH}_{8 \mathrm{w}}$ & 4.2 & 1.6 & 1.8 & 6.0 & 38.1 \\
\hline $\mathrm{pH}$ & 2.7 & 1.1 & 1.5 & 4.4 & 40.7 \\
\hline$\Delta \mathrm{pH} 1$ & 2.1 & 1.8 & 0.0 & 4.8 & 85.7 \\
\hline$\Delta \mathrm{pH} 2$ & 3.6 & 1.2 & 1.9 & 5.4 & 33.3 \\
\hline
\end{tabular}
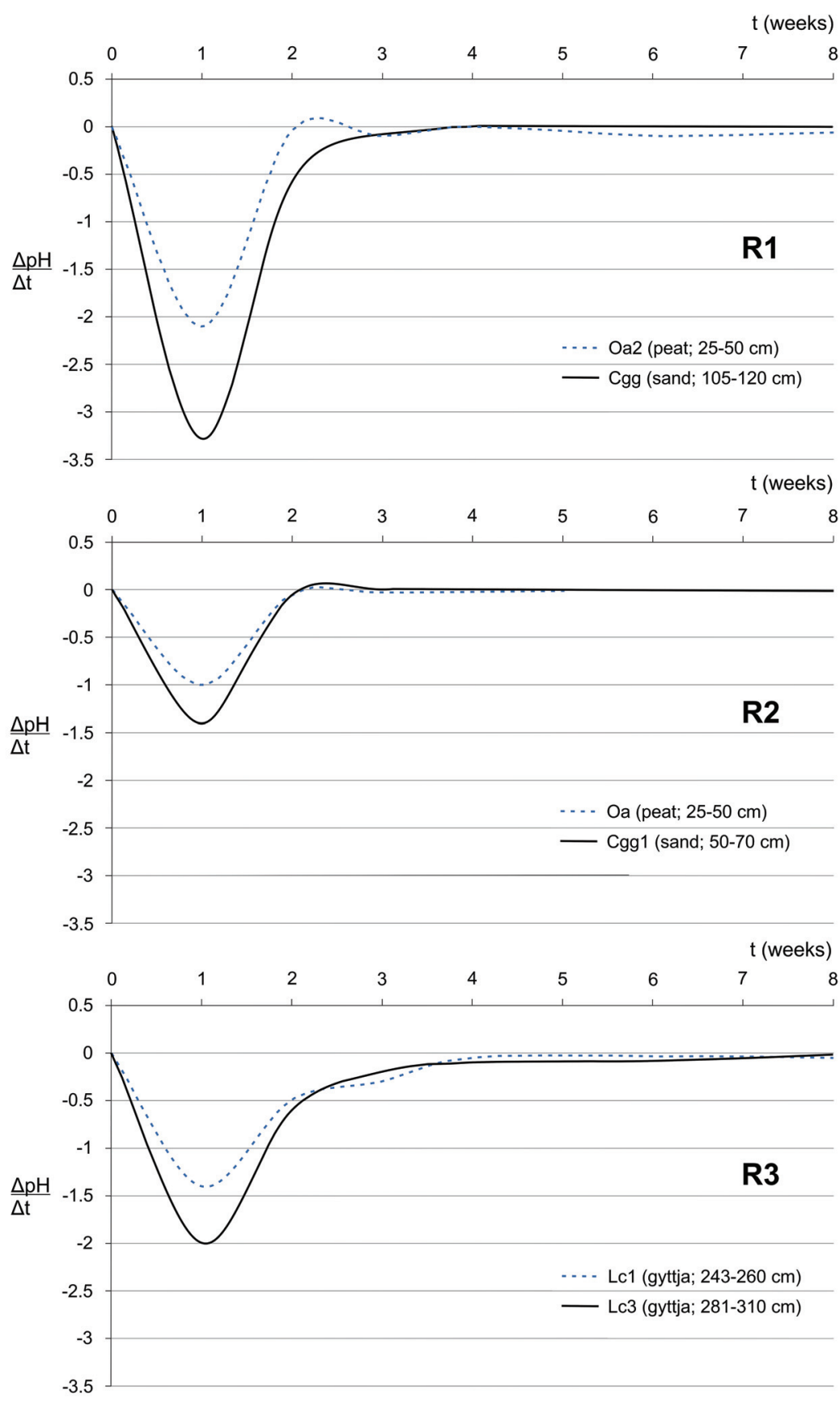
The use of a strong oxidising agent, $30 \% \mathrm{H}_{2} \mathrm{O}_{2}$, resulted in a significant decrease in $\mathrm{pH}$ values $\left(\mathrm{pH}_{\mathrm{pox}}\right.$; Table 1). $\mathrm{pH}_{\mathrm{pox}}$ values below 2.5 were recorded in 13 samples in all three profiles (Fig. 2). The differences between $\mathrm{pH}_{0 \mathrm{w}}$ and $\mathrm{pH}_{\mathrm{pox}}$ were highest in profiles R1 and R3 ( $\Delta \mathrm{pH} 2$ 3.6-5.4).

\section{Discussion}

Soil pH depends on many factors, such as quantity and quality of organic matter, content of calcium and sodium compounds (especially carbonates), clay minerals, aluminium and iron oxides, as well as occurrence of sulfidic material. When the soil becomes strongly acidified as a result of sulfide oxidation, the significance of other factors decreases (Thomas, 2006). The incubation method is one of the oldest methods for recognising sulfide materials on the basis of soil pH measurements (Doyne, 1937; Dent, 1947) and effectively lets the soil 'speak for itself (Dent, 1986). This method is easy to use and inexpensive. On the other hand, the long incubation period is a disadvantage (Andriesse, 1993).

The second method used in this study, oxidation with $30 \%$ $\mathrm{H}_{2} \mathrm{O}_{2}$, allows for identification of hypersulfidic material if the $\mathrm{pH}$ has dropped to 2.5 or less (IUSS Working Group WRB, 2015). When interpreting the results from hydrogen peroxide oxidation, attention should be paid to the following issues (van Breemen, 1973, 1982; Dent, 1986; Langenhoff, 1986): (i) weathered, very fine particles of carbonates in the sample will neutralise the resulting acidification, (ii) in contrast to natural conditions, only one precipitate, $\mathrm{Fe}(\mathrm{OH})_{3}$, is generally produced following iron sulfide oxidation, which may result in lower acidification, (iii) hydrogen peroxide also causes very fast oxidation of organic matter (much faster than during natural conditions); oxidation of organic sulfur to sulfate also increases acidity, (iv) organic acids are also formed as a result of incomplete oxidation of the sample by $\mathrm{H}_{2} \mathrm{O}_{2}$, and (v) under laboratory conditions, acidifying products of the reaction with $\mathrm{H}_{2} \mathrm{O}_{2}$ are not removed by water, as it takes place under natural conditions. All these issues mentioned above affect the $\mathrm{pH}$ of the soil sample and the resulting $\mathrm{pH}$ is generally lower than that measured during field conditions and during incubation. This is also why a lower diagnostic pH-criteria of $\leq 2.5$ (e.g. IUSS Working Group WRB, 2015) is applied when using the hydrogen peroxide method. Additionally, if total acidity (e.g. by titration with $\mathrm{NaOH}$ ) is to be measured after oxidation with hydrogen peroxide, it should be noted that this is not recommended for organic rich materials, as the acidity may be overestimated (i.e. lower $\mathrm{pH}$ ) by the presence of organic acids (e.g. Ward et al., 2002; Sullivan et al., 2018). However, Ward et al. (2002) also showed that the acidity can be underestimated (i.e. higher $\mathrm{pH}$ ) when using hydrogen peroxide due to formation of jarosite from pyrite oxidation and due to buffering from dissolution of clay minerals. In summary, this inexpensive and simple hydrogen peroxide test should be considered more as a preliminary or complementary test, due to the above-mentioned limitations (Andriesse, 1993).

The soil materials described in this paper were characterised by various properties. Mineral materials, such as gleyed sands, are more inertial due to low buffer capacity. The drops in $\mathrm{pH}$ during incubation (oxidation of field-moist samples) were higher in all analysed mineral soil samples than in organic soil materials (peats or gyttjas with low admixture of mineral sediments). The lowest differences in $\mathrm{pH}$ decline, as a function of time, were recorded in the topsoils as a result of intensive pedogenesis (dewatering, oxidation, muck formation, etc.). Similar relationships were observed in the PASS of Karsiborska Kępa Island, NW Poland (Urbańska et al., 2012).

A previous study conducted in the area of the Reda River delta revealed the occurrence of PASS (Pracz and Kwasowski, 2006). However, those authors stated the presence of sulfides, but they did not use methods based on incubation and hydrogen peroxide tests. The soils were characterised by relatively high total sulfur and iron contents, increasing with depth (S 1.6-7.5 $\mathrm{g} \mathrm{kg}^{-1}$ in the topsoil, $2.3-30.8 \mathrm{~g} \mathrm{~kg}^{-1}$ in the subsoil; Fe $1.0-11.6 \mathrm{~g} \mathrm{~kg}^{-1}$ in the topsoil, $3.6-32.1 \mathrm{~g} \mathrm{~kg}^{-1}$ in the subsoil). The $\mathrm{pH}$ values in air-dried samples in the range of 3.2-4.0 and the low C:S ratio (7-22), indicating the presence of sulfides (Pracz, 1989), were recorded in subsoils affected by groundwater.

Both the incubation method and hydrogen peroxide tests allowed the presence of sulfidic material (in Polish: materiat siarczkowy) to be confirmed in profiles R1 and R3. It should be noted that sulfidic material occurred at various depths in the studied soils, often below 100-200 cm (Fig. 2). As for soil classification, this fact is somewhat irrelevant, but it may be important to the appropriate management of the area to avoid potential environmental hazards.

Despite the apparent possible interferences that may lead to either over- or underestimation of the produced acidity and $\mathrm{pH}$, in this study the hydrogen peroxide method was chosen for identifying PASS materials as this is the standard approach in the current WRB classification system (IUSS Working Group WRB, 2015) and Polish Soil Classification (Systematyka Gleb Polski, 2019). However, as can been seen in profile R2 (Fig. 2), where $\mathrm{pH}_{\mathrm{pox}}$ is low ( $\mathrm{pH}$ around 2) but the $\mathrm{pH}_{8 \mathrm{w}}$ is not below the diagnostic $\mathrm{pH}$ level, care must be taken when interpreting the results from the hydrogen peroxide tests. One scenario for profile R2 could be that there are sulfides present, which could be indicated by the $\mathrm{pH}$ drop during incubation, but the presence of $\mathrm{CaCO}_{3}$ buffers the produced acidity to the extent that the $\mathrm{pH}$ does not drop low enough for classification as PASS material. On the other hand, the use of hydrogen peroxide could allow for outmanoeuvring the buffering effect from $\mathrm{CaCO}_{3}$ in $\mathrm{R} 2$ and thus allow for the significant $\mathrm{pH}$ drop as seen in the profile (Fig. 2). In this case the material is not classified as PASS material.

The problem with organic rich materials is that it is very difficult to determine whether or not the $\mathrm{pH}$ drop (and formation of acidity) is due to oxidation of inorganic sulfides or whether it is due to presence of organic acids (often a combination of both). This is the main reason why a lower diagnostic $\mathrm{pH}$ criteria (i.e. $\mathrm{pH}<3.0$ ) is used for incubated organic soil materials in the current Finnish-Swedish classification system (Boman et al., 2018) compared to the current WRB classification (IUSS Working Group WRB, 2015). A similar approach could be considered in the next edition of the Polish Soil Classification. 
The presence of inorganic sulfides could be determined by using the so-called chromium reducible sulfur (CRS) method which effectively targets inorganic sulfur but leaves organically bound sulfur and sulfates (e.g. Canfield et al., 1986; Dalhem, 2016). This method was, however, not used in this study, but it is the author's opinion that it would be a good complement to hydrogen peroxide tests on organic-rich materials.

In Finland, the depth to hypersulfidic material, the so-called critical depth, is recognised during the national mapping of acid sulfate soils (Eden et al., 2012). This knowledge can be used, for instance, during planning of draining activities in areas where acid sulfate soils are present, in farmlands during ditching and installation of sub-surface drainage pipes, in peat excavation areas when peat is removed, and in sand excavation areas for understanding how lowering of the groundwater table may affect sulfide oxidation. It should, however, also be noted that recent studies in Finland (Mattbäck et al., 2017) have shown that the acidifying potential, expressed as the amount of $\mathrm{mmol} \mathrm{H}^{+}$ $\mathrm{kg}^{-1}$ that is formed during oxidation, may differ significantly between various types of acid sulfate soil materials. For instance, fine-grained (clay and silt fractions) and gyttja-containing acid sulfate soil materials often produce 10-100 times more acidity during oxidation compared to coarse-grained (e.g. sand) acid sulfate soil materials (Mattbäck et al., 2017). The incubation pH in both cases is very similar (low $\mathrm{pH}$ and a huge drop during oxidation) and it is therefore difficult to rely solely on incubation $\mathrm{pH}$ in order to indicate the amount of acidity that can potentially be released. Although incubation $\mathrm{pH}$ is very useful for recognising diagnostic properties of acid sulfate soil materials and for mapping the occurrence of acid sulfate soils, other parameters should also be taken into account if the acidifying potential of acid sulfate soils is to be estimated. One such method is to measure the amount of acidity formed during incubation by titrating a soil: $\mathrm{KCl}$ slurry (1:40) with $\mathrm{NaOH}$ to a pH of 5.5 (Mattbäck et al., 2017).

The present study, focusing on $\mathrm{pH}$ measurements under various conditions and analysis of basic soil properties, resulted in the same effect, which confirms the usefulness of the methods used for PASS diagnostics. This approach is still very rarely used in Poland and it is the author's opinion that $\mathrm{pH}$ incubation and hydrogen peroxide tests, due to their versatility, low costs and simplicity of implementation, deserve special attention, both in exploratory research and detailed geochemical mapping of Polish PASS areas.

\section{Conclusions}

1. Two methods suggested in the Polish Soil Classification (2019) for soil oxidation connected with $\mathrm{pH}$ measurements - incubation (slow oxidation), and hydrogen peroxide tests (rapid oxidation) - allowed sulfidic material (in Polish: materiat siarczkowy) to be identified, and thus the presence of potential acid sulfate soils (PASS) to be confirmed in the study area.

2. The rapid rate of decline of $\mathrm{pH}$ values (on average 3-4 units) during incubation of soil samples indicated poor buffering properties and, hence, the high sensitivity of the tested PASS materials to changes in water relations. The largest changes in soil properties occurred in the first two weeks of the oxidation period in both organic and mineral soil samples.

3. It was revealed that the peroxide test can overestimate the acidification risk for the identification of organic PASS, which dominate in the studied area. Therefore, an identification of organic-rich (e.g. peat, mud) acid sulfate soils is more suitable with the $\mathrm{pH}$ incubation method.

4. In the light of our results, it seems reasonable to consider introducing lower diagnostic criteria for identification of the sulfidic material (in Polish: materiat siarczkowy) in organic soils $\left(\mathrm{pH}_{8 \mathrm{w}}<3\right)$ in the next edition of the Polish Soil Classification, similar to the Finnish-Swedish classification system. However, this requires further research, which should be extended to a larger area of Poland.

5. The critical sulfide depth (i.e. start of sulfidic/hypersulfidic material) can be recognised using $\mathrm{pH}$ measurements, but other analyses need to be performed if the acidifying potential, i.e. amount of $\mathrm{H}^{+}\left(\mathrm{mmol} \cdot \mathrm{kg}^{-1}\right)$, is to be determined. Analysis of inorganic sulfides using the CRS-method will confirm the presence of sulfidic materials and will help in interpreting the hydrogen peroxide tests.

\section{References}

Andriesse, W., 1993. Acid sulphate soils: diagnosing the ills. [In:] Dent, D.,L., van Mensvoort, M.E.F. (Eds.), Selected papers of the Ho Chi Minh City Symposium on Acid Sulphate Soils. International Institute for Land Reclamation and Improvement, Wageningen, 11-29.

Andriesse, W., van Mensvoort M.E.F., 2006. Acid sulfate soils: Distribution and extent. [In:] Lal, R. (Ed.), Encyclopedia of Soil Science. Taylor and Francis, New York, 14-28.

Boman, A., Becher, M., Mattbäck, S., Sohlenius, G., Auri, J., Öhrling, C., Edén, P., 2018. Klassificering av sura sulfatjordar i Finland och Sverige (Version 1.2018), 8 pp. (in Swedish). https://vimlavattenorg.files.wordpress.com/2018/07/klassificering_sura_sulfatjordar.pdf [23.7.2019].

Canfield, D.E., Raiswell, R., Westrich, J.T., Reaves, C.M., Berner, R.A., 1986. The use of chromium reduction in the analysis of reduced inorganic sulfur in sediments and shales. Chemical Geology 54, 149-155.

Creeper, N., Fitzpatrick, R., Shand, P., 2012. A simplified incubation method using chiptrays as incubation vessels to identify sulphidic materials in acid sulphate soils. Soil Use and Management 28, 401-408. https://doi.org/10.1111/j.1475-2743.2012.00422.x

Czerwiński, Z., 1996. Zasolenie wód i gleb na Kujawach (Salinity of water and soils in the Kujawy region). Roczniki Gleboznawcze - Soil Science Annual 47(3/4), 131-143.

Dalhem, K., 2016. Bestämning av svavelspecies i sediment: En utvecklad destillationsmetod för reducerade svavelspecies (An advanced analytical method for determining sulfur species in sediments). Manuscript of MSc-thesis. Åbo Akademi University, Geology and Mineralogy, $48 \mathrm{pp}$.

Dent, J.M., 1947. Some soil problems of empoldered rice lands in Sierra Leone. Empire Journal of Experimental Agriculture 15, 206-212.

Dent, D., 1986. Acid sulphate soils: a baseline for research and development. International Institute for Land Reclamation and Improvement, Wageningen.

Dent, D.L., Pons, L.J., 1995. A world perspective on acid sulphate soils. Geoderma 67, 263- 276. https://doi.org/10.1016/0016-7061(95)00013-E

Doyne, H.C., 1937. A note on the acidity of mangrove swamp soils. Tropical Agriculture (Trinidad) 14, 286-287. 
Edén, P., Rankonen, E., Auri, J., Yli-Halla, M., Österholm, P., Beucher, A., Rosendahl, R., 2012. Definition and classification of Finnish acid sulfate soils. 7th International Acid Sulfate Soil Conference, Vaasa. Geological Survey Of Finland, Guide 56, 29-30.

Fältmarsch, R.M., Aström, M.E., Vuori, K.-M., 2008. Environmental risks of metals mobilised from acid sulphate soils in Finland: a literature review. Boreal Environment Research 13, 444-456.

FAO, 2006. Guidelines for soil description. 4th edition. Rome.

Hulisz, P., 2007. Propozycje systematyki gleb zasolonych występujących w Polsce (Proposals of systematics of salt-affected soils in Poland). Roczniki Gleboznawcze - Soil Science Annual 63(1/2), 121-129.

Hulisz, P., 2013. Geneza, właściwości i pozycja systematyczna marszy brakicznych w strefie oddziaływania wód Bałtyku (Genesis, properties and systematics position of the brackish marsh soils in the Baltic coastal zone). Wydawnictwo Uniwersytetu Mikołaja Kopernika w Toruniu, Rozprawy habilitacyjne, 137 pp.

Hulisz, P., Piernik, A., Mantilla-Contreras, J., Elvisto, T., 2016. Main driving factors for seacoast vegetation in the Southern and Eastern Baltic. Wetlands 36, 909-919. https://doi.org/10.1007/s13157-016-0803-2

Hulisz, P., Kwasowski, W., Pracz, J., Malinowski, R., 2017. Coastal acid sulphate soils in Poland: a review. Soil Science Annual 68(1), 46-54.

IUSS Working Group WRB, 2015. World Reference Base for Soil Resources 2014, update 2015. International soil classification system for naming soils and creating legends for soil maps. World Soil Resources Reports, 106, FAO, Rome.

Jayalath, N., 2012. Laboratory protocols for acid sulfate soils. CSIRO, Australia.

Jegliński, W., 2009. The structure and evolution of the contemporary delta of the Reda River (Southern Baltic, Poland). Oceanological and Hydrobiological Studies 38, 27-40.

Kabała, C. et al., 2019. Polish Soil Classification, 6th edition - principles, classification scheme and correlations. Soil Science Annual 70(1), 71-97. https://doi.org/10.2478/ssa-2019-0009

Kondracki, J., 2001. Geografia regionalna Polski. Wyd. Nauk. PWN, Warszawa, $441 \mathrm{pp}$.

Kwasowski, W., 1999. Charakterystyka gleb siarczkowych i kwaśnych siarczanowych rejonu Zatoki Puckiej i okolic Mrzeżyna (Characteristics of the sulphide and acid sulphate soils in the areas of the Puck Lagoon and Mrzeżyno). Manuscript of PhD thesis. SGGW, Warsaw.

Langenhoff, R., 1986. Distribution, mapping, classification and use of Acid Sulfate Soils in the tropics. Stenc nr 6978. Soil Survey Institute (STIBOKA), Wageningen.

Mattbäck, S., Boman, A., Österholm, P., 2017. Hydrogeochemical impact of coarse-grained post-glacial acid sulfate soil materials. Geoderma 308, 291-301. https://doi.org/10.1016/j.geoderma.2017.05.036

Niedźwiecki, E., Protasowicki, M., Czyż, H., Wojcieszczuk, T., Malinowski, R., 2002. Właściwości silnie zakwaszonych gleb Karsiborskiej Kępy znajdujących się pod oddziaływaniem wód rzeczno-morskich (Chemical properties of Karsiborska Kępa island's strongly-acidic soils influenced by riverine-marine waters). Zeszyty Problemowe Postępów Nauk Rolniczych 482, 397-402.

Niedźwiecki, E., Protasowicki, M., Wojcieszczuk, T., Malinowski, R., 2000. Zawartość siarki w glebach wstecznej delty Świny na przykładzie gleb organicznych Karsiborskiej Kępy (Sulphur content in soils of the Świna River reverse delta on the example of organic soils of the Karsiborska Kępa Island). Folia Universitatis Agriculturae Stetinensis 204, Agricultura 81, 97-102.

Pons, L.J., 1973. Outline of the genesis, characteristics, classification and Improvement of acid sulphate soils. Proceedings of International
Symposium on Acid Sulphate Soils, ILRI, Wageningen, 3-27.

Pracz, J., 1989. Właściwości gleb tworzących się przy udziale słonej wody gruntowej w polskiej strefie przybałtyckiej (Properties of soils formed under the influence of saline ground water in the region of the Polish Baltic coast). Rozprawy naukowe i monografie. Wyd. SGGW-AR, Warszawa, 1-91.

Pracz, J., Kwasowski, W., 2005. Organiczne gleby słone występujące w rejonie Zatoki Puckiej (Organic saline soils from the area of the Puck Bay). Roczniki Gleboznawcze - Soil Science Annual 46(3/4), 89-99.

Pracz, J., Kwasowski, W., 2006. Properties of sulphide soils of the Moście Błota peatland at Puck Bay. Polish Journal of Environmental Studies 16(5D), 105-113.

Smith, J., Melville, M.D., 2004. Iron monosulfide formation and oxidation in drain-bottom sediments of an acid sulfate soil environment. Applied Geochemistry 19, 1837-1853. https://doi.org/10.1016/ j.apgeochem.2004.04.004

Staszek, W., Kistowski, M., 1999. Studium uwarunkowań i kierunków zagospodarowania przestrzennego gminy Kosakowo. Uwarunkowania przyrodnicze (Study of conditions and directions of spatial development of the Kosakowo commune. Natural conditions). Biuro Studiów i Pomiarów Proekologicznych EKOMETRIA, Gdańsk, 8 pp.

Sullivan, L.A., Fitzpatrick, R.W., Bush, R. T., Burton, E.D., Shand, P., Ward, N.J., 2010. The classification of acid sulfate soil materials: further modifications. Southern Cross GeoScience Technical Report No. 310. Southern Cross University, Lismore, NSW, Australia.

Sullivan, L., Ward, N., Toppler, N., Lancaster, G., 2018. National Acid Sulfate Soils Guidance: National acid sulfate soils identification and laboratory methods manual. Department of Agriculture and Water Resources, Canberra, ACT.

Systematyka gleb Polski, 2019. Polskie Towarzystwo Gleboznawcze, Komisja Genezy Klasyfikacji i Kartografii Gleb. Wydawnictwo Uniwersytetu Przyrodniczego we Wrocławiu, Polskie Towarzystwo Gleboznawcze, Wrocław Warszawa, 250 pp.

Thomas, G.W., 2006. pH. [In:] Lal, R. (Ed.), Encyclopedia of Soil Science. Taylor and Francis, New York, 263-276.

Urbańska, E., Hulisz, P., Bednarek, R., 2012. Effect of sulphide oxidation on selected soil properties. Journal of Elementology 17(3), 505-515. https://doi.org/10.5601/jelem.2012.17.3.12

Uścinowicz, S., 2006, A relative sea-level curve for the Polish Southern Baltic Sea, Quaternary International 145-146, 86-105. https://doi. org/10.1016/j.quaint.2005.07.007

Uzarowicz, Ł., 2013. Microscopic and microchemical study of iron sulphide weathering in a chronosequence of technogenic and natural soils. Geoderma 197-198, 137-150. https://doi.org/10.1016/ j.geoderma.2013.01.006

Uzarowicz, Ł., Skiba, S., 2011. Technogenic soils developed on mine spoils containing iron sulphides: Mineral transformations as an indicator of pedogenesis. Geoderma 163(1-2), 95-108. https://doi.org/10.1016/ j.geoderma.2011.04.008

van Breemen, N., 1973. Soil forming processes in acid sulphate soils. International Institute for Land Reclamation and Improvement, Wageningen, 66-129.

van Breemen, N., 1982. Genesis, morphology, and classification of acid sulfate soils in coastal plains. [In:] Kittrick, J.A., Fanning, D.S., Hossner, L.R. (Eds.), Acid Sulfate Weathering. SSSA Special Publication 10, 95-108.

Ward, N.J., Sullivan, L.A., Bush, R.T., Lin, C., 2002. Assessment of peroxide oxidation for acid sulfate soil analysis. 2. Acidity determination. Australian Journal of Soil Research 40(3), 443-454. 


\section{Identyfikacja gleb potencjalnie kwaśnych siarczanowych w ujściu rzeki Redy za pomocą pomiarów $\mathrm{pH}$}

\section{Streszczenie}

Gleby potencjalnie kwaśne siarczanowe (ang. potential acid sulfate soils - PASS) są glebami zawierającymi siarczki żelaza, pochodzenia zarówno naturalnego, jak i antropogenicznego. W przypadku obniżenia się poziomu wody gruntowej może dochodzić do utlenienia tych związków i powstania dużych ilości kwasu siarkowego (VI). Przy słabych zdolnościach buforowych gleb skutkuje to silnym zakwaszeniem środowiska, połączonym zwykle z uwalnianiem metali ciężkich do wód gruntowych i powierzchniowych. Większość przeprowadzonych badań PASS w Polsce dotyczyła przede wszystkim podstawowego rozpoznania ich właściwości, a materiał siarczkowy po raz pierwszy wprowadzono do szóstej edycji Systematyki gleb Polski (2019). W związku z tym kluczowe znaczenie mają dalsze szczegółowe badania i wprowadzenie jednolitego podejścia metodycznego. Dlatego też celem niniejszej pracy było zastosowanie metod opartych na pomiarach pH (test inkubacyjny i szybkie utlenianie próbek $30 \% \mathrm{H}_{2} \mathrm{O}_{2}$ ) do identyfikacji materiału siarczkowego w organicznych glebach nadmorskich występujących w rejonie ujścia rzeki Redy (3 profile glebowe). Metody te jako powszechnie stosowane na świecie są zalecane w SGP6. We wszystkich świeżo pobranych próbkach gleby oznaczono $\mathrm{pH}$ w wodzie i po utlenieniu $30 \%$ roztworem $\mathrm{H}_{2} \mathrm{O}_{2}$. Następnie próbki inkubowano przez 8 tygodni w temperaturze pokojowej, dokonując pomiarów pH (w wodzie) co tydzień. Początkowe wartości pH (przed inkubacją) wahały się od 5,5 do 7,0. Po 8 tygodniach inkubacji w próbkach gleb z dwóch profili zanotowano wartości pH poniżej 4,0. Zastosowanie silnego utleniacza, $30 \% \mathrm{H}_{2} \mathrm{O}_{2}$, spowodowało nagły spadek wartości $\mathrm{pH}$ poniżej 2,5 we wszystkich trzech profilach. Uzyskane wyniki pomiarów pH zarówno po inkubacji, jak i po zastosowaniu nadtlenku wodoru pozwoliły na jednoznaczną identyfikację materiału siarczkowego, a tym samym potwierdzenie obecności PASS w rejonie ujścia Redy. W świetle przeprowadzonych badań obydwie metody pomiaru pH wydają się być łatwe do wykonania i tanie, co implikuje ich powszechne zastosowanie w rozpoznawaniu PASS. Należy jednak zwrócić szczególną uwagę na pewne ograniczenia związane $\mathrm{z}$ interpretacją pomiarów $\mathrm{pH}$ w próbkach organicznych potraktowanych $30 \%$ roztworem $\mathrm{H}_{2} \mathrm{O}_{2}$, głównie z powodu możliwego przeszacowania ich kwasowości. Z tego względu procedurę tę należy traktować wyłącznie jako uzupełniającą. W świetle uzyskanych wyników wydaje się słuszne rozważenie wprowadzenia w kolejnym wydaniu Systematyki gleb Polski niższej wartości progowej pH po inkubacji dla wyróżniania materiału siarczkowego w glebach organicznych (tj. $\mathrm{pH}<3$ ), podobnie jak w klasyfikacji fińsko-szwedzkiej. Wymaga to jednak dalszych, szczegółowych badań. 